\title{
Causes for leaving jobs: a comparative analysis
}

\author{
Elena-Sabina Turnea
}

Department of Management, Marketing and Business Administration, Alexandru Ioan Cuza University of Iași, Blvd. Carol I, No. 22, 700505 Iași, Romania; e-mail: sabina.turnea@yahoo.com, sabina.turnea@uaic.ro

\begin{abstract}
Organizational rewards can retain employees at work if are accordingly perceived or can push them to search other jobs that offer the desired rewards, or which satisfy them better. This research is a small piece from a complex study focused on organizational rewards, based on a quantitative method. Data was collected in 2017 in Romania by administrating a questionnaire that had been completed by hand by 627 respondents. The main purpose of the current paper is to find out if there are any differences between three categories of respondents (employed students, employees from Romanian companies and employees from Multinational companies) regarding the reasons that conducted to leaving their last job. The results show that there are no significant differences between these groups if another job in the same area with the studies, better working conditions or misunderstandings with the boss - are considered, while there are significant differences between groups when considering - a better paid job, a job that offers more benefits, stress and other reasons. Most of the employees from the Romanian companies put accent on better wages, at least third from the students left their last job from another in accordance with their studies and for extra benefits and the most invoked reason for leaving jobs because of stress was found to corporatists. The main findings suggest that organizations should seriously pay attention to the causes that conduct to demission and to mitigate them, if possible.
\end{abstract}

Keywords: employees; extra benefits; demission; Romania; stress

\section{Introduction}

Leaving jobs and new jobs can provide to employees, new professional opportunities regarding advancement, career development or new rewards and benefits. But from the point of view of employers, this repeated behavior can generate real problems in the working process, because of the delays in recruiting and selecting new human resources. There are many factors that can generate resignations: better salaries, better working conditions, the desire of advancement, relocation, change of field of activity, etc. These factors are usually related to the organizational reward packages.

The attention to an organizational context in which total reward it is used involves both, the use of intrinsic and extrinsic motivations to achieve a balance in reward management (Zhou et al., 2011). Many studies show that it is appropriate to design a mix for employees that should contain financial rewards, rewards related to the companies' prestige, and rewards specific to work tasks, to increase the staff' contributions to the organizational rewards (Zhou et al., 2011). Employers should fully cover the employees' contributions by using the rewards packages (Sullivan, 2009), and by applying the total reward, employees should 
be attracted, motivated, and retained (Boswell et al., 2011). This paper was designed to find out the main reasons for leaving jobs, which can be used in mitigating these behaviors.

\section{Literature review}

In the information technology domain, there is a shortage of careers, which make employees to consider other professions (Shropshire \& Kadlec, 2012). The alternative options are in fact pushed by stress, job insecurity, and burnout (Shropshire \& Kadlec, 2012). Another study revealed that for maintaining workforce it is necessary to provide a supportive working environment to the employees (Mohammad \& Jahangir, 2014).

The retention in the public organizations it is correlated with the perceived work-life balance by employees, and it is normal to have this result since in public administration activities are better planned as they are in the private sector (Sanjeevkumar, 2012). Organizational commitment and career opportunities are also correlated with staying into the public organizations, because these opportunities are especially for the internal employees (Sanjeevkumar, 2012).

In fact, there are many factors (as constructs) identified as determinants for the option of leaving jobs (Mohammad \& Jahangir, 2014):

- $\quad$ Empowerment and growth;

- Fulfillment of one's job expectations and organization's image;

- $\quad$ Nature of job and updated training;

- $\quad$ Pay and environment;

- $\quad$ Satisfactory job, conditions, and organizational support;

- $\quad$ Sound administration and scope of personal development.

However, opportunities for advancement also lead to employees' satisfaction (Lovett et al., 2004), while dissatisfaction it is associated with stress, low productivity, depression, and intention to leave (Tzeng, 2020). Job satisfaction is negatively correlated with turnover intention, as it shows an empirical investigation made in Pakistan (Rahman et al., 2008).

\section{Methodology and Results}

The objective of the research was to test the differences between students, employees from Romanian companies and employees from Multinational companies, regarding their declared reasons that made them to leave their previous job.

The sample of the research was initially composed by 627 respondents (employed and unemployed), from which 297 employees had resigned at least once from a job. Data was collected in 2016, through a questionnaire administered by hand. Some details about all the participants involved in the study are: age (46.9\% between $18-25$ years; $39.6 \%$ between $26-$ 33 years; $10 \%$ between $34-41$ years; $3.5 \%$ over 41 years); gender (62.5\% female; $37.5 \%$ male); the level of studies (7.2\% high school; $56.6 \%$ undergraduate; $33.7 \%$ master; $2.5 \%$ doctoral programs and other studies).

To test the differences between the 3 considered groups, were established 7 possible causes, which determined 7 hypotheses:

- $\quad$ A better paid job (reason for H1);

- $\quad$ A job in accordance with the studies (reason for $\mathrm{H} 2$ ); 


\section{2nd International Conference on Research In MANAGEMENT}

- $\quad$ A job that offers more benefits (reason for H3);

- $\quad$ Disagreements with the boss (reason for H4);

- $\quad$ Poor working conditions (reason for H5);

- $\quad$ Stress (reason for H6);

- $\quad$ Other reasons (reason for H7).

In Table 1 are presented the reasons for which employees leaved their previous jobs. To obtain these results, it was checked for each respondent the condition of having at least one past job during his/ her professional career.

Table 1: Determinants for leaving the previous job $(N=297)$

\begin{tabular}{|c|c|c|c|c|c|c|c|c|c|}
\hline \multirow[b]{2}{*}{ Variable } & \multirow[b]{2}{*}{ Scale } & \multicolumn{2}{|c|}{$\begin{array}{l}\text { Multination } \\
\text { al Co. }\end{array}$} & \multicolumn{2}{|c|}{$\begin{array}{l}\text { Romanian } \\
\text { Co. }\end{array}$} & \multicolumn{2}{|c|}{ Students } & \multicolumn{2}{|c|}{ Total } \\
\hline & & $\begin{array}{l}\text { Frec } \\
\text { v. }\end{array}$ & $\%$ & $\begin{array}{l}\text { Fre } \\
\text { cv. }\end{array}$ & $\%$ & $\begin{array}{l}\text { Fr } \\
\text { ecv } \\
\text {. }\end{array}$ & $\%$ & $\begin{array}{l}\text { Fr } \\
\text { ecv }\end{array}$ & $\%$ \\
\hline $\begin{array}{l}\text { Finding a better paid } \\
\text { job }\end{array}$ & $\begin{array}{l}\text { "Yes/ } \\
\text { No" }\end{array}$ & 86 & $\begin{array}{l}38 \\
.9\end{array}$ & 29 & $\begin{array}{l}54 . \\
7\end{array}$ & 7 & $\begin{array}{l}30 . \\
4\end{array}$ & $\begin{array}{l}12 \\
2\end{array}$ & $\begin{array}{l}41 \\
.1\end{array}$ \\
\hline $\begin{array}{l}\text { Finding a job according } \\
\text { to studies }\end{array}$ & $\begin{array}{l}\text { "Yes/ } \\
\text { No" }\end{array}$ & 53 & $\begin{array}{l}24 \\
.0 \\
\end{array}$ & 9 & $\begin{array}{l}17 . \\
0\end{array}$ & 7 & $\begin{array}{l}30 . \\
4\end{array}$ & 69 & $\begin{array}{l}23 \\
.2 \\
\end{array}$ \\
\hline $\begin{array}{l}\text { Finding a job that offers } \\
\text { more benefits }\end{array}$ & $\begin{array}{l}\text { "Yes/ } \\
\text { No" }\end{array}$ & 66 & $\begin{array}{l}29 \\
.9\end{array}$ & 9 & $\begin{array}{l}17 . \\
0\end{array}$ & 9 & $\begin{array}{l}39 . \\
1\end{array}$ & 84 & $\begin{array}{l}28 \\
.3 \\
\end{array}$ \\
\hline $\begin{array}{l}\text { Misunderstandings with } \\
\text { the boss }\end{array}$ & $\begin{array}{l}\text { "Yes/ } \\
\text { No" }\end{array}$ & 9 & $\begin{array}{l}4 . \\
1\end{array}$ & 0 & 0.0 & 2 & 8.7 & 11 & $\begin{array}{l}3 . \\
7\end{array}$ \\
\hline Working conditions & $\begin{array}{l}\text { "Yes/ } \\
\text { No" }\end{array}$ & 41 & $\begin{array}{l}18 \\
.6 \\
\end{array}$ & 14 & $\begin{array}{l}26 . \\
4\end{array}$ & 4 & $\begin{array}{l}17 . \\
4\end{array}$ & 59 & $\begin{array}{l}19 \\
.9 \\
\end{array}$ \\
\hline Stress from work & $\begin{array}{l}\text { "Yes/ } \\
\text { No" }\end{array}$ & 42 & $\begin{array}{l}19 \\
.0\end{array}$ & 1 & 1.9 & 1 & 4.3 & 44 & $\begin{array}{l}14 \\
.8\end{array}$ \\
\hline
\end{tabular}

Source: Author's own contribution. Data processed using output from SPSS version 21.0.

$38.9 \%$ from the employees that work in Multinational companies left a previous job for a better paid one, more than half of the employees from Romanian companies made the same choice (54.7\%), and only 30.4\% from students and $\mathrm{PhD}$ students (that work) made the same decision. Several possible causes can justify such choices, such as: increases of personal expenses, personal desire to earn more, or awareness of people that the work they do does not deserve to be remunerated at the level provided by the organization.

In Romania, many students, including PhD students, are working while studying, either to gain experience or for the simple reason that they need money. According to our data, 24\% of the employees from Multinational companies chose a new job according to the studies, $17 \%$ of the employees from Romanian companies made the same choice, and a percentage of $30.4 \%$ of the students emphasized the work-study congruence when leaved their last job. In the questionnaire was explained to the respondents the concept of "benefits", with examples. 29.9\% from the employees from Multinational enterprises chose a new job to have more benefits, $17 \%$ of the employees from Romanian companies made the same choice, and $39.1 \%$ from the students resigned considering this aspect. 


\section{2nd International Conference on Research In MANAGEMENT}

A percentage of $4.1 \%$ of the employees from Multinational companies chose a new job due to the incompatibility with the direct hierarchical boss, none from the Romanian companies made this choice, and a percentage of $8.7 \%$ from the students considered this aspect when leaving the previous job. The disagreements with the boss did not cause many resignations. Such a reason should not appear if problems have been openly discussed with the supervisor and if employees are proactive and have an honest attitude.

A percent of $18.6 \%$ from employees from Multinational companies chose a new job due to poor working conditions, $26.4 \%$ from employees from Romanian companies made the same choice, and $17.4 \%$ of students resigned considering this aspect.

The employees from the Romanian companies were the most affected by the working conditions. On the second place are the respondents who currently work in Multinationals. The least affected group by this cause is that with students. To obtain organizational and individual performance, employees need airy, clean and lighted rooms, access to recreation areas, ergonomic furniture, etc. A healthy workforce involves good working conditions.

As it can be seen in the previous table, $19 \%$ from the employees from Multinational companies chose a new job due to stress, $1.9 \%$ from the employees from Romanian companies made this choice, and a percentage of $4.3 \%$ of students considered this aspect when leaving the previous job.

In Table 2 are presented the Kruskal Wallis' values and the p values useful in testing the hypotheses of the study.

Table 2: The Kruskal Wallis Test for testing the hypotheses

\begin{tabular}{|l|l|l|l|l|l|l|l|}
\hline & $\begin{array}{l}\text { A } \\
\text { better } \\
\text { paid } \\
\text { job } \\
\text { (H1) }\end{array}$ & $\begin{array}{l}\text { A job in } \\
\text { accordance } \\
\text { with the } \\
\text { studies } \\
\mathbf{( H 2 )}\end{array}$ & $\begin{array}{l}\text { A job } \\
\text { that } \\
\text { offers } \\
\text { more } \\
\text { benefits } \\
\text { (H3) }\end{array}$ & $\begin{array}{l}\text { Disagreements } \\
\text { with the boss } \\
\text { (H4) }\end{array}$ & $\begin{array}{l}\text { Poor } \\
\text { working } \\
\text { conditions } \\
\text { (H5) }\end{array}$ & $\begin{array}{l}\text { Stress } \\
\text { (H6) }\end{array}$ & $\begin{array}{l}\text { Other } \\
\text { reasons } \\
\text { (H7) }\end{array}$ \\
\hline $\begin{array}{l}\text { Chi- } \\
\text { Square }\end{array}$ & 5.559 & 1.893 & 4.928 & 3.717 & 1.750 & 12.049 & 5.046 \\
\hline df & 2 & 2 & 2 & 2 & 2 & 2 & 2 \\
\hline p values & $0.062 * *$ & 0.388 & $0.085^{* *}$ & 0.156 & 0.417 & $0.002 *$ & $0.080^{* *}$ \\
\hline
\end{tabular}

Source: Author's own contribution. Data processed using output from SPSS version 21.0.

The value of $\mathrm{p}$ was set to the significance lower than 0.1 , which it is transposed into a confidence level of at least $90 \%$. As it can be seen, the following hypotheses obtained significant p values: $\mathrm{H} 1, \mathrm{H} 3, \mathrm{H} 6$ and $\mathrm{H} 7$.

For a better view of the testing, in Table 3 are named the hypotheses and synthetized the results of testing. 
2nd International Conference on Research In MANAGEMENT

19 _21 February, 2021

Vienna, AUSTRIA

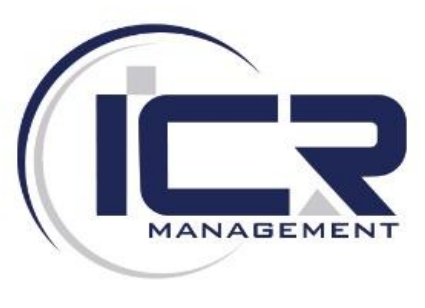

Table 3: The validation of the hypotheses

\begin{tabular}{|c|c|c|c|}
\hline Code & Hypothesis & $\begin{array}{l}\text { Test used for } \\
\text { validation }\end{array}$ & Result \\
\hline H1 & $\begin{array}{l}\text { There are significant differences between } \\
\text { students, employees from Romanian } \\
\text { companies and employees from } \\
\text { Multinational companies regarding the } \\
\text { leaving from the last job for a better paid } \\
\text { job }\end{array}$ & \multirow{7}{*}{$\begin{array}{c}\text { Kruskal } \\
\text { Wallis Test }\end{array}$} & VALIDATED \\
\hline $\mathbf{H} 2$ & $\begin{array}{l}\text { There are significant differences between } \\
\text { students, employees from Romanian } \\
\text { companies and employees from } \\
\text { Multinational companies regarding the } \\
\text { leaving from the last job for a job according } \\
\text { to the studies }\end{array}$ & & $\begin{array}{c}\text { NOT } \\
\text { VALIDATED }\end{array}$ \\
\hline H3 & $\begin{array}{l}\text { There are significant differences between } \\
\text { students, employees from Romanian } \\
\text { companies and employees from } \\
\text { Multinational companies regarding the } \\
\text { leaving from the last job for a job that offers } \\
\text { more benefits }\end{array}$ & & VALIDATED \\
\hline H4 & $\begin{array}{l}\text { There are significant differences between } \\
\text { students, employees from Romanian } \\
\text { companies and employees from } \\
\text { Multinational companies regarding the } \\
\text { leaving from the last job due to } \\
\text { disagreements with the boss }\end{array}$ & & $\begin{array}{c}\text { NOT } \\
\text { VALIDATED }\end{array}$ \\
\hline H5 & $\begin{array}{l}\text { There are significant differences between } \\
\text { students, employees from Romanian } \\
\text { companies and employees from } \\
\text { Multinational companies regarding the } \\
\text { leaving from the last job due to poor } \\
\text { working conditions }\end{array}$ & & $\begin{array}{c}\text { NOT } \\
\text { VALIDATED }\end{array}$ \\
\hline H6 & $\begin{array}{l}\text { There are significant differences between } \\
\text { students, employees from Romanian } \\
\text { companies and employees from } \\
\text { Multinational companies regarding the } \\
\text { leaving from the last job because of stress }\end{array}$ & & VALIDATED \\
\hline H7 & $\begin{array}{l}\text { There are significant differences between } \\
\text { students, employees from Romanian } \\
\text { companies and employees from } \\
\text { Multinational companies regarding the } \\
\text { leaving from the last job for other reasons }\end{array}$ & & VALIDATED \\
\hline
\end{tabular}




\section{Conclusion}

The objective of the research was to test the differences between students, employees from Romanian companies and employees from Multinational companies, regarding their declared reasons that made them to leave their previous job.

The main results show that there are no significant differences between these groups if another job in the same area with the studies, better working conditions or misunderstandings with the boss - are considered, while there are significant differences between groups when considering - a better paid job, a job that offers more benefits, stress and other reasons.

Most of the employees from the Romanian companies put accent on better wages, at least third from the students left their last job from another in accordance with their studies and for extra benefits and the most invoked reason for leaving jobs because of stress was found to corporatists. The main findings suggest that organizations should seriously pay attention to the causes that conduct to demission and to mitigate them, if possible.

\section{Acknowledgment}

This work was cofinanced from the European Social Fund through Operational Programme Human Capital 2014-2020, project number POCU/380/6/13/125015 "Development of entrepreneurial skills for doctoral students and postdoctoral researchers in the field of economic sciences".

\section{References}

Boswell, W.R., Cook, A.L., Horner, M.T., Payne, S.C., Shaub, M.K. (2011), The relative influence of Total Rewards Elements on Attraction, Motivation and Retention, WorldatWork Journal, vol. 20(1), pp. 1-45.

Lovett, S., Coyle, T. and Adams, R. (2004). Job Satisfaction and Technology In Mexico, Journal of World Business, vol. 39(3), pp. 217-232.

Mohammad, F.I. and Md. Jahangir, A. (2014). Factors influencing Intention to Quit or Stay in Jobs: An Empirical Study on selected sectors in Bangladesh, Stamford Journal of Business Studies, vol. 6(1), pp. 142-164.

Rahman, A., Vaqvi Raza, S.M.M. and Ramay Ismail, M. (2008). Measuring Turnover Intention: A Study of It Professionals in Pakistan, International Review of Business Research Papers, vol. 4(3), pp.45-55.

Sanjeevkumar, V. (2012). A Study On Employee's Intension To Stay In Public Companies, International Journal Of Business Economics \& Management Research, vol. 2(4), pp. 91-101.

Shropshire, J. and Kadlec, C. (2012). I'm Leaving the IT Field: the Impact of Stress, Job Insecurity, and Burnout on IT Professionals, International Journal of Information and Communication Technology Research, vol. 2(1), pp. 6-16.

Sullivan, N. (2009). Total reward: Bells and whistles, Employee Benefits, pp. 27-28.

Tzeng, H.M. (2002). Are We Satisfying Our Nurses on The Factors They Care For? An Empirical Study in Taiwan, Journal of Nursing Administration, vol. 32(6), pp. 867-878. 
2nd International Conference on Research In MANAGEMENT

Vienna, AUSTRIA

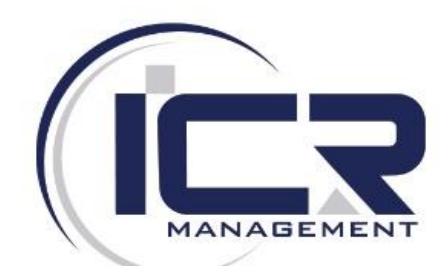

Zhou, Y., Zhang, Y. and Montoro-Sánchez, Á. (2011). Utilitarianism or romanticism: the effect of rewards on employees' innovative behaviour, International Journal of Manpower, vol. 32(1), pp. 81-98. 